\title{
Kadamba Tank Cultivation Area: A Status of Agricultural Sector
}

\section{OPEN ACCESS}

Manuscript ID:

ECO-2020-08043353

Volume: 8

Issue: 4

Month: September

Year: 2020

P-ISSN: 2319-961X

E-ISSN: 2582-0192

Received: 18.07.2020

Accepted: 28.08 .2020

Published: 01.09.2020

Citation:

Marimuthu, M. "Kadamba Tank Cultivation Area: A Status of Agricultural Sector." Shanlax International Journal of Economics, vol. 8, no. 4, 2020, pp. 43-47.

DOI:

https://doi.org/10.34293/ economics.v8i4.3353

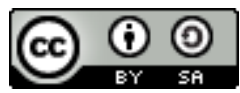

This work is licensed under a Creative Commons Attribution-ShareAlike 4.0 International License

\section{Marimuthu}

Assistant Professor, Department of Economics

Dr. Zakir Husain College, Ilayangudi, Tamil Nadu, India

D https://orcid.org/0000-0001-6585-8727

\section{Abstract}

The Thamirabarani River is one of the prominent sources of water for Kadamba Tank. Thamirabarani river is the perennial river in the South Tamil Nadu. Apart from that, which can store water during the North-East Monsoon period. The water user association members are getting money from duck rears and allowing duck into the agriculture fields after the harvest. The agriculturist is saying that after the first harvest if the water is not sufficient for the next crop such as paddy, farmers can go for the crop such as zero water consumption crops like green gram, black gram. Because of duck farming, agriculturists are not able to get benefited from low-cost crops. Indeed, water is the scarcity of resources in Tamil Nadu; irrigation water should not be charged more. Like other places in Tamil Nadu, in Kadamba Kulam agriculture basin, also collecting charges (ayakatu) for water usage by the association. The nonavailability of water throughout the year, the agricultural labors are moved from native and employed in the industrial sector. Tamil Nadu is a water tense state that lingers to experience water shortages which are expected to exacerbate in future due to the political pressure and money laundering, Justices A. Selvam and P. Kalaiyarasan dismissed the petitions on several grounds, including the State government's submission that only $43 \mathrm{mc} f \mathrm{ft}$ out of 5,049 mcf of surface water that goes waste into the sea was being supplied to the two industries. The court said that such supply did not affect either irrigation or drinking water needs of the people in any way.

Keywords: Zero water consumption crops, Kadamba tank, Middle men, Ayakatu, Water user association and Meagre income.

\section{Introduction}

Kadamba Tank is phrased in Classical Language Tamil by Kadalil path Kadamba that means it is half to the ocean. In olden days many kings in Tamil Nadu had constructed larger tanks for irrigating the agriculture crops. In this study, the researcher is the most part focusing on the performance of Water User Association, Water availability for crop growing, water cost, and intermediaries problem in the Kadamba tank planting area in the agricultural sector. The Thamirabarani River is one of the outstanding sources of water for Kadamba Tank. Thamirabarani river is the eternal river in South Tamil Nadu. Thamirabarani river gives water for the three districts in Tamil Nadu. They are Tirunelveli, Thoothukudi, and Virudunagar. Kadamba tank can store water during the North-East Monsoon. Thamirabarani river basin is particularly to environmental changes due to its bulky population, the predominance of agriculture. The irrigation sector will be strongly affected by the Sterlite copper industry, Spic and Thermal Power station.

\section{Review of Literature}

Puri, B. N. (1968), explained in Gujarat irrigation gave much importance. People reserve water during the rainy season and use the same water during the nonrainy period. 
Rao, V. M., and M. G. Chandrakant. (1984) Resources at the Margin: Tank Irrigation Programme in Karnataka, examined about the tank is the high cost and weak impact resources. Fourteen percent of the tank water would be lost through evaporation, and another 10 percent would be surplus water. It is unused by water users in the rainy season.

Balasubramanian, R, and R. Govindasamy. (1991) Ranking irrigation tanks for modernization explained that repairing or modernization is very difficult for an individual; it costs very high. This paper explained the modernization of an irrigation tank that can be done by the water user association.

Shankari, Uma. (1991) explained tank irrigation is very important to the semi-arid area. This paper discussed tank irrigation is very old for Southern parts of the Indian agriculture system. But due to the poor rain fall agriculturists forget to maintain the common property resources in the Chittoor district of Andhra Pradesh. Hence, revitalize tank irrigation is a very critical importance in the study area.

S. Janakarajan. (1993) In Search of Tanks: Some Hidden Facts, examined traditional irrigation and water user association and their institutional factors. In the institutional setup, tank irrigation is partially neglected. The study explained that traditional water users and institutions could be separated because both of them should use water from the same place.

Palanisami, K., and J. C. Flinn. (1998) Evaluating the Performance of Tank Irrigation Systems, explained daily using data relating to weather, tank hydrology, and farmer-related inputs of common property resources and studied on stress days, rice yield reduction, and income distribution in head and tail end of the tank irrigation operating system.

Sakurai, T, and K. Palanisami. (2001) Tank irrigation management as a local common property: the case of Tamil Nadu, India, this paper examined that $90 \%$ of farmers will use wells for agriculture at present, well users are only $37 \%$. But according to this study, in the future, 90 percent of the farmers will use wells for the cultivation. Because of the nonperformance of the water user association and the poor tank maintenance.

Path, Balasaheb Vikhe (2008) has identified rural indebtedness is an obstacle for development. This article is precise about the improvement in credit release, but a correction in the arrangement approach is more important. No Credit actions alone tackle the problem.

Shah, Esha (2008) explained that the modernization of the tank is very important at the same time culture should not be spoiled. He examined society is a very important one. Society is made up of culture. Culture is made up of people. Researchers explained culture and technology should go hand in hand. If culture is spoiled, technological knowledge will spoil the economy.

Palanisami, K et al. (2010) examined the challenges faced by tank irrigation and how to improve the performance and income generation. In India, especially in southern India like Tamil Nadu and Andhra, where high-intensity floods and droughts are expected in the future. This paper suggested that increasing water storage is a key adaptation strategy through irrigation tanks. This paper also illustrates both the potential and challenges of the Tank irrigation adaptation response. This paper suggested that income can be generated with the help of integrating social forestry and desilting.

Jiang, Qiuxiang, Qiang Fu, and Zilong Wang. (2011) examines the spatial heterogeneity and correlations of soil properties. This study explains the site was separated into two subzones and representing that the delineation of irrigation management zones was sensible.

Narayanamoorthy, A. (2011) in this study, the researcher has attempted to analyze the past development of the irrigated area across Tamil Nadu. This study explained that the growth in the irrigated area across the states and sources had decreased heavily. This study has examined the comparison between the post-green revolution period and the green revolution period. The study explained tank irrigation is a low cost one. Even though it is low-cost one also tank irrigation has declined sharply since the mid-1960s; this has created an acute shortage of lively hood problems for farmers relying on tank irrigation for cultivating agriculture crops.

Pingle, Gautam (2011) examined that from 1956 to 2009 state Telangana lost 2.92 lakh hectares of tank irrigation due to the high cost of irrigation on both the capital and operating costs. It has happened due to the lack of rain fall over the study period. 
Hence, the study has suggested that Telengana people have converted the irrigation through tube wells.

Sezen, S. Metin, et al (2011) examines the effects of different partial root zone use of drip-irrigated sunflower under field conditions in 2006 and 2007 in the eastern Mediterranean region of Turkey. This study revealed that under a water shortage condition, PRD-50 is a satisfactory irrigation plan to increase sunflower yield and quality.

Jana, Sebak Kumar, et al (2012), A Study on Tank Irrigation Productivity in the Dry Zones of West Bengal, this paper explained about crop diversification. This paper examines to improve the productivity of the tanks; the tank water user can use extension activities like multiple crop systems.

Basole, Amit (2017) says $70 \%$ of the agricultural family units cannot meet theirs below consumption needs. Article acquire materially on rural employment opportunities.

\section{Objective of the Study}

- The study is to understand the condition of agriculturists in the Kadamba tank agriculture area.

- To understand the activities of the water user association in the Kadamba tank agriculture area.

- To understand the problems faced by agriculturists in the Kadamba tank agriculture area.

\section{Significance of Research}

The study is limited to the performance of the water user association in the Kadamba Tank agricultural area. Since the Tamirabarani river is the perennial river, and Kadamba tank is the biggest agriculture tank in south Tamil Nadu. Here farmers are cropping rice twice in a year and once zero water consumption crops. Hence, a study on Water User Association performance is inevitable to study.

\section{Types of Research}

The study is based on descriptive.

\section{Performance of Water User Association}

Tank irrigation system, to hand three number of reaches. They are head reach, middle reach, and tail-end reach. Accordingly, the agriculturist forms a Water User Association. In Kadamba tank is also having the association but not working right during these days. Because of the nonavailability of plenty of water over the rainy season.

Since there is less rainfall than the regular on yearly rainfall of Tamil Nadu and India for the last three years from 2015 to 17 , but the growing industry is very higher in Thoothukudi and Tirunelveli districts in Tamil Nadu. Because of Thoothukudi seaports and Special Economic Zones in the Head reach of the Tamirabarani river basin.

The water user association members are getting money from duck rears and allowing duck into the agriculture fields after the harvest. The agriculturist is saying that after the first harvest if the water is not sufficient for the next crop such as paddy, farmers can go for the crop such as zero water consumption crops like green gram, black gram. Because of duck farming, agriculturists are not able to get benefited from low-cost crops.

\section{Water Cost}

Indeed, water is the scarcity of resources in Tamil Nadu; irrigation water should not be charged more. Like other places in Tamil Nadu, in Kadamba Kulam agriculture basin, also collecting charges (ayakatu) for water usage by the association. They are saying that that money is using for the maintenance of the tank. But the tank is not cleared the top layered (sediments) for very long periods.

\section{Climate Change}

As the common man, Kadamba tank agriculturists are also not escaped from the climatic change or irregular rainfall in the offseason. The Indian agriculturists are born in debt, live in debt, and die in debt. This statement is also not free from Kadamba Tank agriculturist. Because of the irregular rainfall in the offseason, paddy plants are devasted, and farmers are not able to repay the loans which have taken from the banks and money lenders.

\section{Middlemen}

Kadamba tank agriculturists are not free from Middlemen like other places in India. But here the problems are a little different from other places. Because of the nonavailability of water throughout 
the year, agricultural laborers are moved from native and employed in the industrial sector. Because of the less supply of labor and their prices went up. Due to that cost of production increases, but the price for the goods is not increased for the paddy crops. In the Kadamba tank irrigation basis, the agriculture sector is facing the problem of the small and marginal size of lands.

Because of the nonavailability of labor for harvesting, different types of middle men are evolving in the agricultural sector. They are middle men for procuring goods, middle men for bringing the harvest machines from different places. The middle men are requesting the harvesting machine operator to harvest the crop slowly. The cost of a machine for one hour for harvest is Rs. 2200. Due to that cost of production is going high up to the level of the sky. Finally, agriculturists are getting only mere income. Their condition is very poor, and their productivity level has come down (Vaidyanathan, A. et al. 1994).

\section{Conclusion of the Study}

The universal truth that water scarcity and drought are the extensive curb of agricultural production in the whole world. Agriculture is the elementary occupation of the Tamirabarani river basin. Since 2014, Because of the failure of the monsoon, the District Collector of Tirunelveli and Thoothukudi is not allowed farmers to do agriculture in the area. But the head reach of the Thamirabarani river basin, the Government of Tamil Nadu, has put the plant of SIPCOT (State Industries Promotion Corporation of Tamil Nadu). Inside the SIPCOT premises, there are 25 industries, including PepsiCo and Coca Cola. They can draw water; only 43 might. The two companies devour tremendous quantities of water, guessed 3 million gallons of water per day. In 2016, Public Interest Litigation was directly filed by a group of the public in the Madurai bench of the Madras high court. On March 2, 2017, the Madurai bench of the Madras High Court dismissed a combination of public interest litigation (PIL) petitions filed against the supply of the Tamirabarani river water by SIPCOT to the industries set up by PepsiCo and Coca-Cola. Because of the political pressure and money laundering, Justices A. Selvam and P. Kalaiyarasan dismissed the petitions on several grounds, counting the State government's acquiescence that only $43 \mathrm{mc} \mathrm{ft}$ out of 5,049 mcf of top water that unuse into the sea was being supplied to the two industries. The court said that such stockpile did not affect either irrigation or drinking water rights of the people in any way. Due to the Court decision, the status of agriculture in the Kadamba Tank is very poor, and agriculturists are not able to repay the loan. Because of the money lenders and bank loans, farmers should not go for suicide. If this continues in the future, the people should buy packed water from PepsiCo and Coca-Cola for irrigation purposes in the Thamirabarani river basin.

\section{References}

Balasubramanian, R., and R. Govindasamy. "Ranking Irrigation Tanks for Modernization." Agricultural Water Management, vol. 20, no. 2, 1991, pp. 155-162.

Basole, Amit. "What Does the Rural Economy Need? Analysis of the Promises for Rural India." Economic \& Political Weekly, vol. 52, no. 9, 2017.

Dhas, Albert Christopher. "Agricultural Crisis in India: The Root Cause and Consequences." MPRA Paper 18930, University Library of Munich, 2009.

Imranullah, Mohamed S. "Madras HC Rejects plea to stop Tamirabarani Water Supply to Soft Drink Units.” The Hindu, 2017.

“India inks \$318 Million World Bank Loan for Tamil Nadu Irrigation Scheme." Financial Express, 2017.

Jana, Sebak Kumar, et al. "A Study on Tank Irrigation Productivity in the Dry Zones of West Bengal." Indian Journal of Agricultural Economics, vol. 67, no. 2, 2012, pp. 225-237.

Janakarajan, S. "In Search of Tanks: Some Hidden Facts." Economic and Political Weekly, vol. 28, 1993, pp. 53-60.

Jiang, Qiuxiang, et al. "Delineating Site-Specific Irrigation Management Zones." Irrigation and Drainage, vol. 60, no. 4, 2011, pp. 464-472.

Mathur, Archana S., et al. "Status of Agriculture in India: Trends and Prospects." Economic 
and Political Weekly, vol. 41, no. 52, 2006, pp. 5327-5336.

Mitra, Sounak and Dharani Thangavelu. "CocaCola, PepsiCo get Court Relief in Tamil Nadu amid Retail Boycott." Livemint, 2017.

Narayanamoorthy, A. "Development and Composition of Irrigation in India: Temporal Trends and Regional Patterns." Irrigation and Drainage, vol. 60, no. 4, 2011, pp. 431-445.

Palanisami, K, et al. "Climate Change and Water Supplies: Options for Sustaining Tank Irrigation Potential in India." Economic and Political Weekly, vol. 45, no. 26/27, 2010, pp. 183-190.

Palanisami, K., and J.C. Flinn. "Evaluating the Performance of Tank Irrigation Systems." Agricultural Systems, vol. 28, no. 3, 1988, pp. 161-177.

Path, Balasaheb Vikhe. "Agricultural Indebtedness: Crisis and Revival." Economic and Political Weekly, vol. 43, no. 5, 2008, pp. 47-52.

Pingle, Gautam. "Irrigation in Telangana: The Rise and Fall of Tanks." Economic and Political Weekly, vol. 46, no. 26/27, 2011, pp. 123-130.

Puri, B.N. "Irrigation and Agricultural Economy in Ancient India." Annals of the Bhandarkar Oriental Research Institute, vol. 48/49, 1968, pp. 383-390.

Rao, V.M., and M.G. Chandrakant. "Resources at the Margin: Tank Irrigation Programme in Karnataka." Economic and Political Weekly, vol. 19, 1984, pp. 54-58

Sakurai, T., and K. Palanisami. "Tank Irrigation Management as a Local Common Property: the Case of Tamil Nadu, India." Agricultural Economics, vol. 25, no. 2-3, 2001, pp. 273283.

Saravanan, L. "Madras HC dismisses PIL against supply of Thamirabarani River Water to Industries." The Times of India, 2017.

Sezen, S. Metin, et al. "Effects of Partial Root Zone Drying and Deficit Irrigation on Yield and Oil Quality of Sunflower in a Mediterranean Environment." Irrigation and Drainage, vol. 60, no. 4, 2011, pp. 499-508.

Shah, Esha. "Telling Otherwise: A Historical Anthropology of Tank Irrigation Technology in South India." Technology and Culture, vol. 49, no. 3, 2008, pp. 652-674.

Shankari, Uma. "Tanks: Major Problems in Minor Irrigation." Economic and Political Weekly, vol. 26, no. 39, 1991, pp. 115-125.

Singh, Hemant. "What is the Sector-wise Contribution of GDP in india?." Jagranjosh, 2020.

Suri, K.C. "Political Economy of Agrarian Distress." Economic and Political Weekly, vol. 41, no. 16, 2006, pp. 1523-1529.

Vaidyanathan, A., et al. "Impact of Irrigation on Productivity of Land." Journal of Indian School of Political Economy, vol. 6, no. 4, 1994, pp. 601-645.

\section{Author Details}

Dr. M. Marimuthu, Assistant Professor, Department of Economics, Dr. Zakir Husain College, Ilayangudi, Tamil Nadu, India, Email ID: marimuthu1007@gmail.com. 